\title{
Recent Trends of Fire Occurrence in Sumatra (Analysis Using MODIS Hotspot Data): A Comparison with Fire Occurrence in Kalimantan
}

\author{
Nina Yulianti ${ }^{1}$, Hiroshi Hayasaka ${ }^{1}$, Alpon Sepriando ${ }^{2}$ \\ ${ }^{1}$ Graduate School of Engineering, Hokkaido University, Sapporo, Japan \\ ${ }^{2}$ Meteorological, Climatology and Geophysical Agency of Central Kalimantan, Palangkaraya, Indonesia \\ Email: Nina@eng.hokudai.ac.jp
}

Received June 21 $1^{\text {st }}, 2013$; revised August $6^{\text {th }}, 2013$; accepted August $21^{\text {st }}, 2013$

Copyright (C) 2013 Nina Yulianti et al. This is an open access article distributed under the Creative Commons Attribution License, which permits unrestricted use, distribution, and reproduction in any medium, provided the original work is properly cited.

\begin{abstract}
MODIS (Moderate Resolution Imaging Spectroradiometer) hotspot and precipitation data for the most recent 11-year period (2002 to 2012) were analyzed to elucidate recent trends in the seasonal and spatial fire occurrence in Sumatra and the relationship with precipitation. Using a latitude line of S $0.5^{\circ}$, Sumatra was divided into two regions, N. (north) and S. (south) Sumatra. Different trends in seasonal fire occurrence were discussed and further defined by considering two different precipitation patterns. Analysis of hotspot (fire) data was carried out using $0.5^{\circ} \times 0.5^{\circ}$ grid cells to evaluate recent trends of spatial fire occurrence. Analysis results of hotspot and precipitation data were also tallied every 10-day to find the relationship between seasonal fire occurrence and the dry season. Standard deviation (SD) and variance (V) were then used to evaluate fire occurrences in Sumatra and Kalimantan objectively. The relatively mild fire occurrence tendency in Sumatra compared to Kalimantan could be the result of different stages of forest development or the high deforestation rate in Sumatra compared with Kalimantan. This paper also shows that the two different seasonal fire activities in N. and S. Sumatra were closely related to the two different dry season types: a winter and summer dry season type $\left(W_{D} \& S_{D}\right)$ in N. Sumatra, and a summer dry season type $\left(S_{D}\right)$ in S. Sumatra. Extreme fire occurrences in the Dumai region in 2005 and Palembang region in 2006 could be partially explained by a severe drought occurrence enhanced by two different kinds of El Niño events.
\end{abstract}

Keywords: Drought; Dry Season; El Niño; MODIS Hotspot; Peatland Fire

\section{Introduction}

During 1997 and 1998, areas of forest measured approximately $45,000 \mathrm{~km}^{2}$ were destroyed by extreme fires in Kalimantan and Sumatra, releasing more than 2.6 gigatonnes of $\mathrm{CO}_{2}$ to the atmosphere (Tacconi, 2003), and causing a transboundary haze event in South East Asia. An estimate of the size of the area burned in East Kalimantan alone, between January and April 1998, was 52,000 $\mathrm{km}^{2}$ (Siegert et al. 2001). In addition to this vast amount of damage, the fires caused serious health and economic problems within the region (Dennis, 1999). Since then, Sumatra and Kalimantan have experienced frequent fire occurrences, but as discussed in our preliminary paper, (Yulianti et al., 2012), the number has diminished. It is notable that the frequent fire occurrence in Sumatra coincides with the rapid rate of deforestation occurring over the past 10 -years (2000-2012), which has been at a rate of about $23.7 \% /(10-\mathrm{yr})$ for all forests and 5.2\%/(yr) for peat swamp forest (Miettinen et al., 2011a).

Since 1990, deforestation in Sumatra has contributed to a loss of 7.45 million hectares in an area of primary forest measured 75,000 $\mathrm{km}^{2}$ (Margono et al., 2012); a faster rate than in Kalimantan. In other words, the present area of forest in Suma- tra $\left(120,000 \mathrm{~km}^{2}\right)$ is smaller than that of Kalimantan $(250,000$ $\mathrm{km}^{2}$ ), as officially reported by the Ministry of Forestry of Indonesia (MoF, 2012). It is also evident that most fires are related to agriculture activity, and this is consistent with Sumatra being home to the largest industrial plantations in Indonesia $\left(15,280 \mathrm{~km}^{2}\right.$ Joosten et al., 2012), as well as the most prolific cultivation of palm oil (10,467 km², Miettinen et al., 2012).

During development of the Tidal-coast Development Project, which began in the late 1960s in Sumatra (Furukawa, 2004), for instance, the swamp drainage channels caused a noticeable reduction in the dry season water table (Fearnside, 1997) and provided a low ground water level environment, which is very suitable for the occurrence of peat fires. This also occurred in the MRP area in Kalimantan (Putra \& Hayasaka, 2011). Slashing and burning activities associated with the rapidly increasing number of plantation crops and industrial forests, have destroyed the peat swamp forests in both Kalimantan and Sumatra. This has caused serious environmental problems, and longburning fires occur from January to October every year (Yulianti et al., 2012). For instance, vegetation fires in the southern peatland of Sumatra, often occur in relation to burning activities within the plantations during the dry season (Stolle et al., 2003). 
Once a fire begins, its behavior is highly dependent on the prevailing environmental factors, such as the weather conditions and the desiccated state of the material to be burned. Rainfall conditions are an extremely important factor in the tropical zone, and rainfall patterns can be affected by active fire, particularly on peatland areas (Putra \& Hayasaka, 2011). The characteristics of fires in the Sumatra peatland areas are also influenced by the rate of decomposition of the peat, as described in Saharjo (2005). Under dry conditions, peat that is more highly decomposed (mature) is very flammable and results in a longer period of smoldering fire, as discussed by Usup et al. (2004). Thus, the emissions of carbon solely from peat fires in Southeast Asia, (mostly from the Sumatran and Kalimantan peatlands) are very similar to emissions from the whole of Sub-Saharan Africa (Harris et al., 2012). However, vegetation fires related to forest clearing activities tend to be more widespread in Sumatra, even outside peatland or undeveloped areas which are far from sea coast. Recent frequent fires related to deforestation in the Riau areas of North Sumatra Province have also become a global environmental issue, due to the amount of $\mathrm{CO}_{2}$ emitted (3.6 Giga tons $\mathrm{CO}_{2}$; Uryu et al., 2008).

The use of satellite-based monitoring enables a more comprehensive understanding and evaluation of fire activities inside forest areas, and also in large peatland areas. Since 2002, the MODIS sensor on board the Terra and Aqua satellites has covered the whole of Indonesia. Several earlier studies using MODIS hotspot data have focused on Asia (Vadrevu \& Justice, 2011), Southeast Asia (Miettinen et al., 2011b), and Borneo (Langner \& Siegert, 2009). Our previous research analyzed the recent fire trends during the MODIS era for Indonesia (Yulianti et al., 2012), and Kalimantan (Borneo part of Indonesia, Yulianti \& Hayasaka, 2013). Peat fire activity in the MRP area was discussed in Putra \& Hayasaka (2011). However, there have only been a few reports related to fires in Sumatra.

In this study, we carefully analyzed the seasonal and spatial occurrence of fire using the last 11-year (2002-2012) of MODIS hotspots (fire) and the last 12-year (2001-2012) of precipitation data. We attempted to determine trends in the seasonal and spatial occurrence of fire under severe drought conditions in north and south Sumatra separately. Analysis of seasonal fire occurrence was carried out using hotspot and precipitation data at 10-day intervals from January to December. Fire (hotspot) distribution maps were drawn to identify active fire areas in Sumatra for the analysis of spatial fire occurrence. The results of similar research that was conducted on Kalimantan fires by Yulianti and Hayasaka (2013), were compared to the above-mentioned analyses, to observe typical trends in the occurrence of peatland fires in Sumatra and to enable an effective, future peatland fire forecast.

\section{Methodology}

\section{Study Area and Peatland}

The study area covers Sumatra Island from $\mathrm{N} 6^{\circ}$ to $\mathrm{S} 6^{\circ}$ and from E $95^{\circ}$ to $108^{\circ}$ (Figure 1). Sumatra covers a total land area of about $474,000 \mathrm{~km}^{2}$ (approximately $89.1 \%$ of the size of Kalimantan which covers $532,000 \mathrm{~km}^{2}$ ). The total peatland area of Sumatra is about $72,000 \mathrm{~km}^{2}$, which is approximately $15 \%$ of the land area of Sumatra; (Wetlands, 2003), (120\% larger than that of Kalimantan at $58,000 \mathrm{~km}^{2}$ ). (The distribution of peatland is shown in a dark color (brown) in Figure 1). The main area of peatland in Sumatra has developed in a large area of lowland on

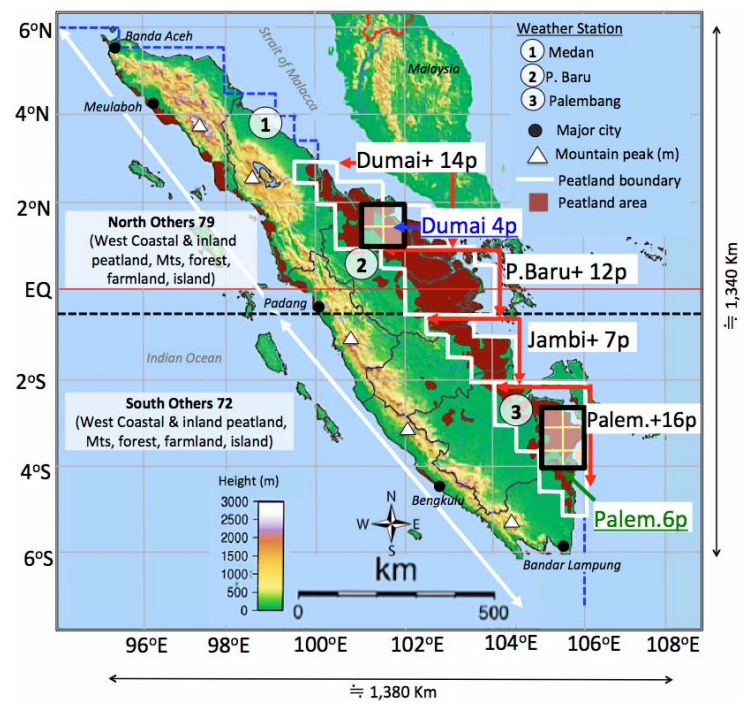

Figure 1.

Map of peatland, weather stations, and the eight regions used for analysis in Sumatra.

the east coast, covering a distance of roughly $1200 \mathrm{~km}$ from the north of Dumai in Riau ( $\left.\sim \mathrm{N} 2.6^{\circ}\right)$ to the north of Lampung $(\sim \mathrm{S}$ $5^{\circ}$ ), and covering a distance of nearly $200 \mathrm{~km}$ (maximum distance) inland from the coast. Other several small areas of peatland are independently located on the west coast and inland, (west of Riau, Jambi and Palembang). North Sumatra has the deepest area of peatland, at a depth of around $9 \mathrm{~m}$ (Jauhiainen et al., 2011); in S. Sumatra the depth is shallower, at about $4 \mathrm{~m}$ (Wetlands, 2003). Nowadays, major areas of peatland are maintained by large plantation companies by the provision of drainage systems. However, many of these use unsuitable systems for the preservation of peatlands, and cause a very low ground water level).

In this paper, in order to clarify spatial and seasonal fire occurrences in Sumatra, the authors have given suitable names to regions. The borders of these regions are different from those used in conventional political and geographical maps. We achieved this by dividing Sumatra into two regions, N. (north) and S. (south) Sumatra, by using a latitude line of S $0.5^{\circ}$ and with consideration of the following: two different precipitation patterns (Aldrian \& Susanto, 2003), an historical climatic map showing precipitation patterns in Sumatra (Oldeman et al., 1979), and a previous study by Chang et al. (2005), (as shown in Figure 1).

Analysis using a $0.5^{\circ}$ grid cell provided approximately 105 and 95 cells for N. and S. Sumatra respectively. These cells in N. and S. Sumatra were then grouped into regions, to clarify the spatial and seasonal fire occurrence, particularly for areas of peatland (shown in Figure 1). The borders of these regions were constructed on the connecting lines from the rectangular analysis cells $\left(0.5^{\circ}\right.$ grid cell). We then allocated suitable regional names, such as "Dumai + 14" (14 cells, a subset of North Sumatra and Riau Province), "Pekan Baru + 12" (12 cells for a subset of Riau Province) in N. Sumatra, "Jambi + 7" (7 cells, a subset of south Riau and Jambi Province) and "Palembang + 16" (16 cells, a subset of South Sumatra and north Lampung Province) in S. Sumatra. Borders of these four regions are shown by the lines in Figure 1. We put "+" after each 
region to show the expanded region of each local area name (such as "Dumai+"), so as to avoid confusion with the conventional administrative name. The number provided at the end of the names is used to describe the number of cells that the region occupies. The other two regions, and the remaining cells from the above four regions, were simply named N. Others (79 cells), and S. Others (72 cells). Finally, two special areas, Dumai 4 in N. Sumatra and Palembang 6 in S. Sumatra, were introduced to highlight the extreme fire activities in these areas in 2005 and 2006.

\section{MODIS Hotspot Data and Grid Analysis}

Daily MODIS hotspot data (Collection 5.1 active fire product) from the most recent 11-year period (2002 to 2012) were automatically extracted from the FIRMS website (Fire Information for Resources Management System, http://earthdata.nasa.gov/ data/near-real-time-data/data/firms) and were then analyzed in this paper. Approximately 250,000 hotspots were recovered from the 11-year data for Sumatra, (which includes Insular Malaysia).

In this paper, $0.5^{\circ}$ grids were used to clarify the spatial trend of fire occurrence. Hotspots were tallied depending on their longitude and latitude. For a hotspot density, units of "hotspots/cell," and "hotspots $/ \mathrm{km}^{2}$," were used. The approximate area of these grid cells at the equator is $3070 \mathrm{~km}^{2}$, and this was used for the conversion to hotspot density, "hotspots $/ \mathrm{km}^{2}$ ".

\section{Weather and Precipitation Data}

To determine the relationship between fire activity on peatland and weather patterns, we attempted to obtain weather data from many places in Sumatra, but were only able to purchase daily precipitation data from six stations. In this paper, we analyzed precipitation data for the most recent 12-year period (2001 to 2012) measured at three airports (see Figure 1) in Medan (Polania, N 3.66 ${ }^{\circ}$ E $98.60^{\circ}$, North Sumatra), Pekan Baru (Sultan Syarif Kasim II, N $0.47^{\circ}$, E $101.45^{\circ}$, Riau), and Palembang (Sultan Mahmud Badaruddin II, S 2.90', E $104.70^{\circ}$ South Sumatra). All data belongs to the Indonesia Meteorological, Climatology and Geophysical Agency (BMKG).

Precipitation data measured at three weather stations in $\mathrm{Su}-$ matra were tallied every 10-day to define the dry season period and to explain the different trends in fire occurrence in N. and S. Sumatra. Data processing from every 10-days was applied instead of using other data smoothing periods of a 10-day (week) and 30-day (month), because the smoothing of data over a period of 10-day is less difficult than over other time periods. In addition, the 10-day period will enable us to label seasons by using expressions such as, "early June," instead of "DN $=152$ to 161 ".

\section{Results and Discussions}

\section{Dry Season Type, Period, and Lowest Daily Mean Precipitation}

Precipitation patterns for three weather stations (Medan, Pekan Baru (known as P. Baru), and Palembang) were calculated using the recent 12-year interval from 2001 to 2012 (see Figures 2(a)-(c)). In total, 35 mean daily precipitation values for every 10-day interval, were calculated for each station, and are shown by the solid lines in the graphs in Figure 2. Each daily mean precipitation value was placed on its representative

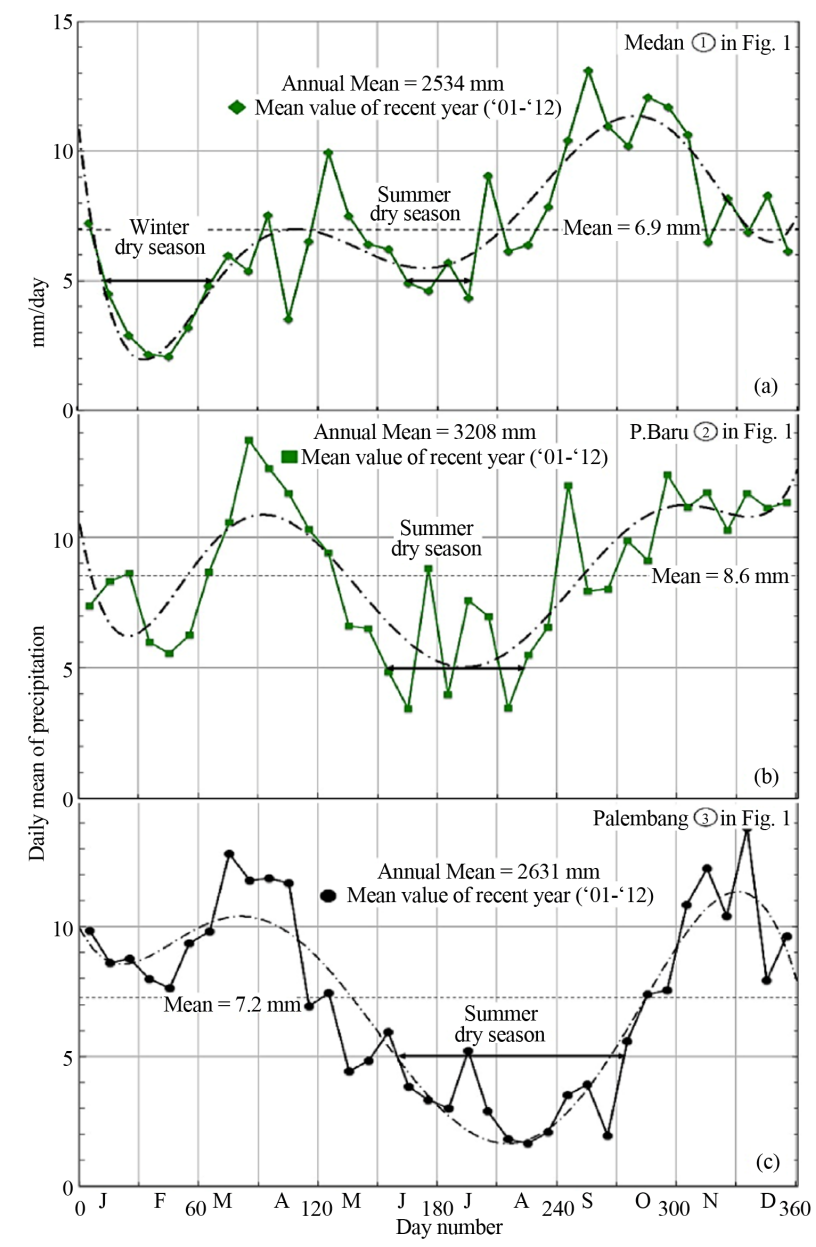

Figure 2.

Dry season period in: (a) Medan; (b) Pekan Baru; and (c) Palembang derived from 12-year (2001-2012) data.

point from $\mathrm{DN}=5$ to $\mathrm{DN}=355$ within the 10 -day interval. In addition, simple smoothed curves (dotted lines) have been added to the graph, representing the daily mean precipitation. With the help of these two lines, we were able to ascertain the dry season period and the low precipitation values during each dry season, for each station.

The definition of a dry season period for each area in this paper, follows previous analysis of Kalimantan by Yulianti \& Hayasaka, (2013), and the daily mean precipitation of 5 $\mathrm{mm}$ /day was used as a threshold value for the dry season. By using the line for daily mean precipitation in our graph in Figure 2, we can see that threshold value is apparent in Medan (N $\left.3.66^{\circ}\right)$ in the Northern Hemisphere, revealing an approximately two month winter dry season in January and February $\left(\mathrm{W}_{\mathrm{D}(2)}\right)$ and a summer dry season $\left(\mathrm{S}_{\mathrm{D}(2)}\right)$ in June and July. In Palembang $\left(\mathrm{S} 2.90^{\circ}\right)$ in the Southern Hemisphere, there was a relatively long dry season, about 4-month $\mathrm{S}_{\mathrm{D}(4)}$ from June to September, and in P. Baru ( $\left.\mathrm{N} 0.47^{\circ}\right)$ near the Equator, (located between Medan and Palembang, see Figure 1), there was an intermediate dry season, or a one-month quasi-winter dry season with rain (daily mean precipitation in February higher than 5.5 $\mathrm{mm} /$ day), and a dry season of about 2-months $\mathrm{S}_{\mathrm{D}(2)}$ in June and August.

The lowest values of daily mean precipitation during the 
above-mentioned dry seasons were an indication of fire activities near each weather station. In Medan, the lowest values of daily mean precipitation in $\mathrm{W}_{\mathrm{D}(2)}$ and $\mathrm{S}_{\mathrm{D}(2)}$ found in Figure 2(a) were about $2.1 \mathrm{~mm} /$ day in February and $4.3 \mathrm{~mm} /$ day in July respectively. In Palembang, the lowest value in Figure 2(c) was $1.7 \mathrm{~mm} /$ day in $\mathrm{S}_{\mathrm{D}(4)}$ in August. In P. Baru, the lowest value was $3.4 \mathrm{~mm} /$ day, from only one period in each of June and August, as shown in Figure 2(b). Moreover, the annual mean precipitation of P. Baru (about $3200 \mathrm{~mm}$ ) was higher than the amounts of about 2500 and $2600 \mathrm{~mm}$ from the other two weather stations. Reasons for this were that we could estimate that the heavy precipitation in P. Baru would mainly be due to the effect of the mountain behind the area (see Figure 1).

\section{Fire Prone Areas and Peatland}

Fire prone areas $(>100$ hotspots/(yr. cell) in the most recent 11-year period (2002 to 2012) are highlighted using different colors in Figure 3. Most of these areas are located on the eastern side of Sumatra, but some are in the northern part. There were 12 cells showing a very high hotspot density ( $>400$ hotspots $/(\mathrm{yr}$. cell $)=0.129$ hotspots $\left./\left(\mathrm{yr} \mathrm{km}^{2}\right)\right)$. These cells were named $\mathrm{H} 1, \mathrm{H} 2, \ldots, \mathrm{H} 12$, in descending order of hotspot density. The 7 highest hotspot density cells (H1 4, H8, H11 and H12), located in the Dumai region or Dumai $+14 p$ (Dumai4p: H1, H3, H4, and H12), cover most of the northeast coast peatland in N. Sumatra (Riau Province). According to the peatland map (Wetlands, 2003), the Dumai region contains a peat layer that is relatively deeper $(\sim 8 \mathrm{~mm})$ than other places in S. Sumatra and Kalimantan (except the MRP area). It is of note that Dumai + $14 \mathrm{p}$ belongs to a different climate zone than most of S. Sumatra and Kalimantan (see Figures 2(a) and 3).

The seventh highest cell, H7, is located on the eastern side in Pekan Baru (capital of Riau Province) near the Equator and on the coast. The other highest cells, H5, H6, H9, and H10, are located in the region of S. Sumatra. H5 and H6 are located on the eastern side at Palembang (capital of the South Sumatran Province), and two cells in Palembang 6p. H9 in the south in

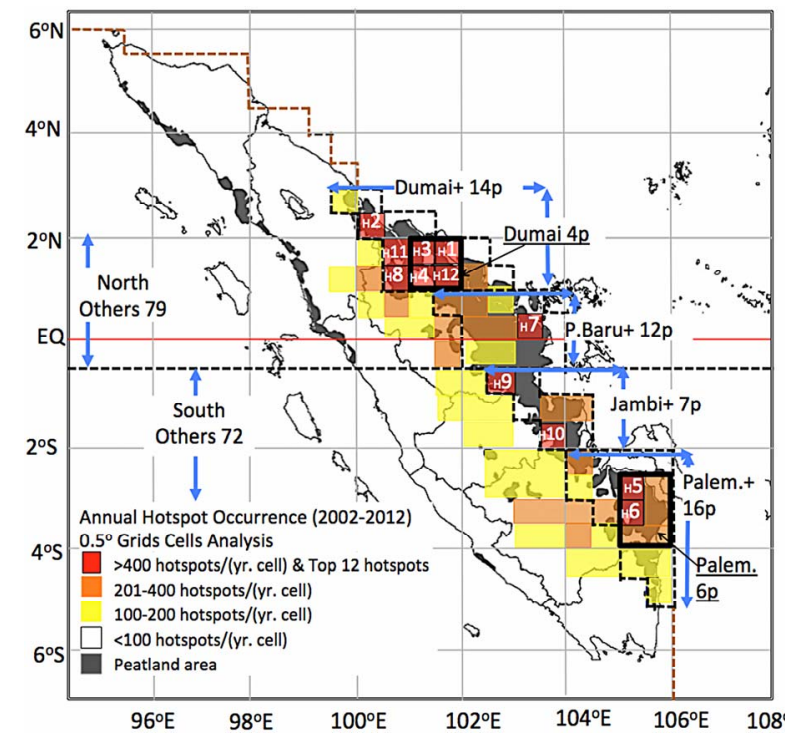

Figure 3.

Map of the 12-highest hotspot cells, fire prone cells, and peatland in Sumatra.
Pekan Baru, and H10 in southeast Jambi are two cells included in Jambi $+7 p$ (see Figure 3).

From the distribution of these highest hotspot cells, it is evident that the most recent fires in Sumatra have occurred mainly on the coastal peatland. Many of the fires on peatland can be explained by the history of development as in the MRP area of Kalimantan (Furukawa, 2004). Areas in the MRP with dense hotspots were related to high human activity such as deforestation, slash and burn clearing, and the maintenance of plantations (Yulianti et al., 2012).

\section{Recent Fire Occurrence Trends in Sumatra}

\section{Annual and Average Seasonal Fire Occurrence in} N. Sumatra

The stacked bar graph in Figure 4 shows the number of fires that have occurred in three regions in N. Sumatra (from bottom to top: Dumai +14, P. Baru $+12 p$, and North Others 79 ). The annual mean numbers of fires in these three regions and those in S. Sumatra, (and the annual fire in Kalimantan), are shown in the two bars on the far right in Figure 4. The unit of the Y-axis is the number of hotspots in each region.

The annual mean number of hotspots in N. Sumatra over the past 10 -years was about 8600 , and $60 \%$ of these fires occurred in peatland areas (Dumai $+14 p$ and P. Baru $+12 p$ ). A comparison of the two bars in Figure 4, shows that the number of fires in 2005, (about 27,000 hotspots/yr.), is larger than the average number in Kalimantan (23,000 hotspots/yr.). About $80 \%$ of the extreme fires in 2005 occurred mainly in peatland in the Dumai and P. Baru regions; areas responsible for approximately 16,000 and 5400 fires $(60.3 \%$ and $20.4 \%)$ respectively. Fire occurrences in both peatland areas were 4.2 times larger than in the North Others 79, which is predominantly non-peatland.

The occurrence of fires in most years (6 out of the 10 years) in N. Sumatra was in the range of $+1 \sigma$ to $-1 \sigma$. The variance of fire occurrence $(\mathrm{V})$ of about $(3900)^{2}$ was smaller than that of about $(16,000)^{2}$ in Kalimantan. This relatively stable fire occurrence in N. Sumatra may suggest that the occurrence of socalled routine fires on plantations and developed land are not so strongly related to the weather conditions, and the yearly fire

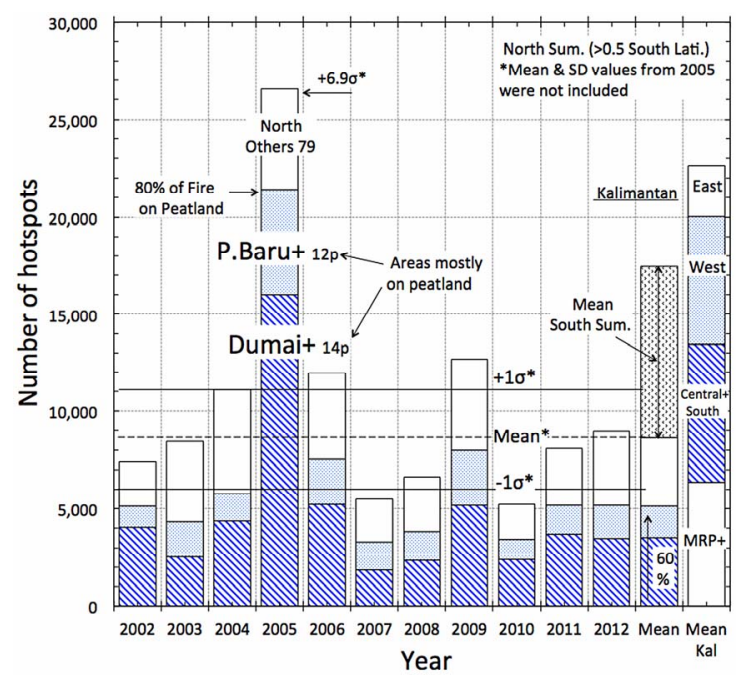

Figure 4.

Recent trends in annual fire occurrence in N. Sumatra. 
occurrences could be related to agriculture activities such as agricultural residue burning. Small-sized fire occurrence could, therefore, imply that large land clearing or deforestation activities are no longer taking place in N. Sumatra.

The extreme fire occurrences in Dumai $+14 p$ in 2005 was an exceptional case, and the main cause of these severe fires was due to the expansion of fires lit for land clearing and agricultural activities. On inspection of weather data measured at Medan, (located about $400 \mathrm{~km}$ northeast of Dumai), these fires may also have occurred during severe drought conditions. In Medan, the drought lasted for about two months, from mid-January to mid-March in 2005, and overlapped with the dry season in N. Sumatra.

In this paper, to clarify the average seasonal fire occurrence tendency in N. Sumatra, the average number of hotspots every 10-days (1/3-month) were calculated. In doing so, one active fire area named "Dumai $4 \mathrm{p}$ " was extracted from a part of Dumai $+14 p$, to illustrate the seasonal fire occurrence clearly.

From Figure 5, it can be seen that the seasonal fire occurrence trend in N. Sumatra displays two major fire seasons: one fire peak in February and one in March, and another from May to August. Such seasonal fire peaks can be partially explained by the two precipitation patterns and the dry season periods for

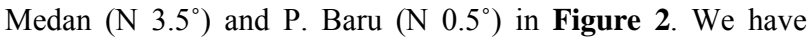
observed that, firstly, the winter fire peak in February (in Figure 5) is mainly due to fires occurring in Dumai $4 \mathrm{p}\left(\mathrm{N} 1.8^{\circ}\right)$ and P. Baru $+12 p$. These fires correspond to the winter dry seasons WD found in Figures 2(a) and (b). The highest fire peak for Dumai $4 p$ (mid-February) corresponds to the lowest daily mean precipitation (about $2 \mathrm{~mm} /$ day) in Figure 2(a). Secondly, the early summer peak in June in Figure $\mathbf{5}$ is mainly due to fires occurring in North Others 79 and Dumai $+14 p$. These fires can be mainly explained by the summer dry season in P. Baru in Figure 2(b), because the low latitude 32 cells $(<\mathrm{N}$ 2.5 ) in North Others 79 are responsible for about $80 \%$ of the fires, and these cells have a similar rainfall pattern to P. Baru. Thus, most fires in N. Sumatra tend to occur under a rainfall condition of about $3.5 \mathrm{~mm} /$ day in mid-June, as seen in Figure 2(b). Thirdly, the highest fire peak in the whole of N. Sumatra occurs in early August. This peak in August is mainly due to the increased number of fires in P. Baru under the lowest daily rainfall of about $3.5 \mathrm{~mm} /$ day. Such a tendency may, therefore, imply the occurrence of peat fires in P. Baru+.

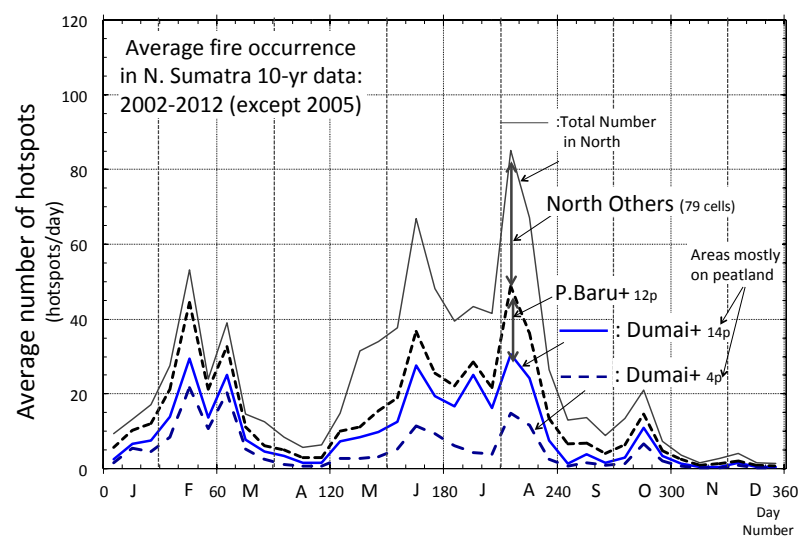

Figure 5.

Recent trends of average seasonal fire occurrence in N. Sumatra.

\section{Annual and Average Seasonal Fire Occurrence in S. Sumatra}

The annual mean number of fires in S. Sumatra is shown in Figure 6 (using a similar graph format to Figure 4). The stacked bar graph in Figure 6 shows the number of fires in three regions in S. Sumatra, from bottom to top: Palembang + $(16 p)$, Jambi $+(7 p)$, and South Others 72 . The annual mean number of fires in the three regions (excluding 2006), and the annual number of fires in Kalimantan, are shown by the two bars on the far right in Figure 6.

The annual mean number of hotspots in S. Sumatra during the last 10 -years was about 8900 , and, approximately $47 \%$ of the fires occurred in peatland areas (Palembang+ and Jambi+). Fire data from 2006 were excluded from the statistics calculation, due to severe fire occurrence $(+5.3 \sigma,+2.6 \sigma$ if the data from 2006 are included) under the drought enhanced by El Niño in 2006. A comparison of the two bars in Figure 6, shows that the number of fires in 2006, (about 29,000 hotspots/yr.), was larger than that of the average number in Kalimantan (23,000 hotspots/yr.). About 57\% of these extreme fires in 2006 occurred mainly in peatland areas in the Palembang+ and Jambi+ regions, which are responsible for around 13,300 and 3300 fires $(45.5 \%$ and $11.4 \%)$, respectively. The occurrence of fires in both these peatland areas was 1.3 times larger than that in South Others (mostly non-peatland).

The fire occurrence in the majority of years in S. Sumatra, $(6$ out of the 10 years), was within the range of $+1 \sigma$ to $-1 \sigma$ and the variance of fire occurrence $(\mathrm{V})$ of an area of around $(7200)^{2}$ was smaller than that of an area of about $(16,000)^{2}$ in Kalimantan, but larger than that of an area of about $(5900)^{2}$ in N. Sumatra. The relatively stable fire occurrence in S. Sumatra may also suggest that continual and small-size fire occurrences are not strongly related to weather conditions, as in N. Sumatra. It is evident that the occurrence of small fires in heavy rain conditions during 2010 could have made the variance of fire occurrence in S. Sumatra larger than that in N. Sumatra.

The extreme fire occurrence in Palembang+ in 2006 was an exceptional case and the main cause of these severe fires was due to an expansion of fires for land clearing and agricultural

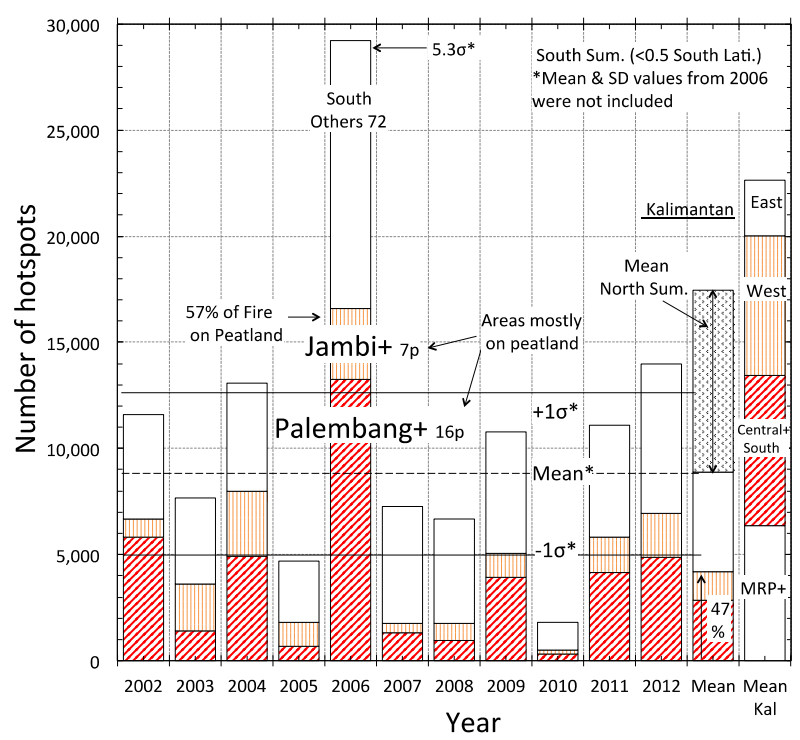

Figure 6.

Recent trends in annual fire occurrence in S. Sumatra. 
activities, and which occurred under severe drought conditions lasting three months from early August to late October in 2006, and which overlapped with the dry season in S. Sumatra.

Figure $\mathbf{7}$ is similar to that of Figure 5 for N. Sumatra, and was used to clarify the average seasonal fire occurrence tendency in S. Sumatra. By using this graph, one fire active area named "Palembang 6p," was defined and extracted from one part of Palembang $+16 p$, to clearly illustrate the seasonal fire occurrence.

From Figure 7, the trends of seasonal fire occurrence in S. Sumatra show one fire season from May to late October, with a few peaks in September. This one-fire-season pattern in S. Sumatra almost corresponds to the one-summer-dry-season pattern in Figure 2(c). The difference in the fire peak in September of about one month in Figure 7 and the low of precipitation in August in Figure 2(c) can be estimated using the author's previous research related to Kalimantan, where we found there was a time lag of approximately one month between precipitation and a rising ground water level (Putra \& Hayasaka, 2011). This result was obtained from measurement results in peatland in Block C, the MRP, in Central Kalimantan (Takahashi et al., 2007).

From Figure 7 the highest peak can be seen in late September for all three regions in S. Sumatra. Palembang $6 p$ had the same values as the MRP area in Central Kalimantan, (Yulianti \& Hayasaka, 2013). This could suggest that peat fires in S. Sumatra and south Kalimantan occur under a similar weather condition created by the southern monsoon during the summer months (between May and October).

\section{Recent Extreme Fire Occurrences in Sumatra}

\section{Highest Hotspot Cell in Sumatra}

Extreme fire occurrences were observed in both $\mathrm{N}$. and $\mathrm{S}$. Sumatra in 2005 and 2006 respectively. The cells with the top 12 highest hotspot densities ( $>400$ hotspots/yr.) in Figure 3 were mainly due to the occurrence of these extreme fires. The top four highest hotspot cells from $\mathrm{H} 1$ to $\mathrm{H} 4$ are located near
Dumai, and two cells of H5 and H6 are near Palembang. A comparison of the seven highest cells from the top 12 highest hotspot density cells in Kalimantan (Yulianti \& Hayasaka, 2013) are listed in Table $\mathbf{1 .}$

From Table 1, the fires in $\mathrm{H} 1$ near Dumai could be referred to as "extreme" fires, because the average and the maximum number of hotspots in H1 were 941 and 4494, respectively. The average number in $\mathrm{H} 1$ was almost the same as the value of 971 in the H1k cell in Kalimantan. However, the greatest value in H1 (4494) was the highest overall. SD values of 2.77 - 2.94 for the four highest cells in Sumatra were higher than those values (1.45 - 2.4) in Kalimantan (seen in Table 1). These differences could imply that the extreme fires in Sumatra with higher SDs were incidental fires. In contrast, the extreme fires in Kaliman$\tan$ with lower SDs were routine fires lit for the purpose of development. The seasonal occurrence of these extreme fires in Sumatra is discussed in the sections below.

\section{The Extreme Seasonal Fire Occurrence and Drought in N. Sumatra (2005)}

In Figure 8, seasonal fire occurrence and drought in $\mathrm{N}$. Su-

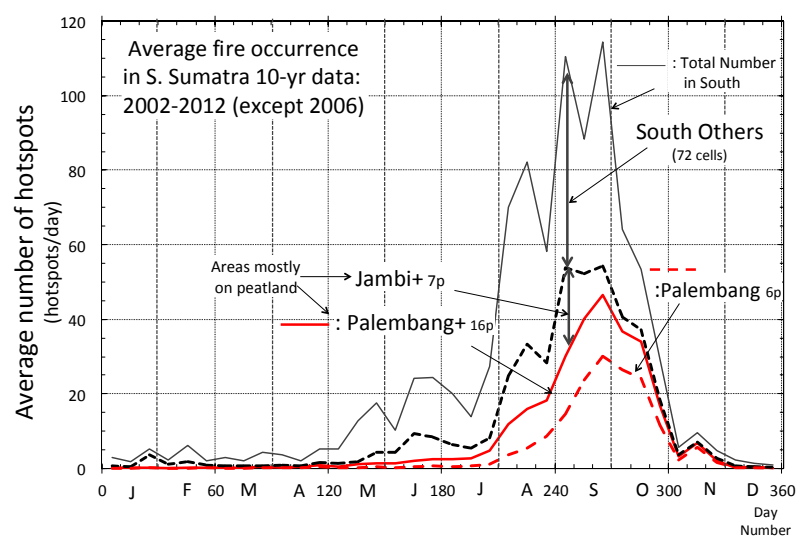

Figure 7.

Recent trends in average seasonal fire occurrence in S. Sumatra.

Table 1.

Comparison of the highest hotspot cells in Sumatra and Kalimantan.

\begin{tabular}{ccccccc}
\hline & Rank & Ave. & Max. & SD $(\sigma)$ for Max. & Year for Max. & Region \\
\hline \multirow{5}{*}{ Sumatra } & H1 & 941 & 4494 & 2.94 & 2005 & Dumai 4p (east) \\
& H2 & 686 & 2385 & 2.77 & 2005 & Dumai (northwest) \\
& H3 & 624 & 2231 & 2.85 & 2005 & Dumai4p \\
& H4 & 483 & 772 & 1.35 & 2006 & Dumai4p (south) \\
& H5 & 477 & 2966 & 2.95 & 2006 & Palembang (east) \\
& H1k & 971 & 2417 & 1.76 & 2006 & MRP (C south) \\
Kalimantan (C north) \\
\end{tabular}

*Ave.: 11-year (2002-2012) for Sumatra, 10-year (2002-2011) for Kalimantan. 


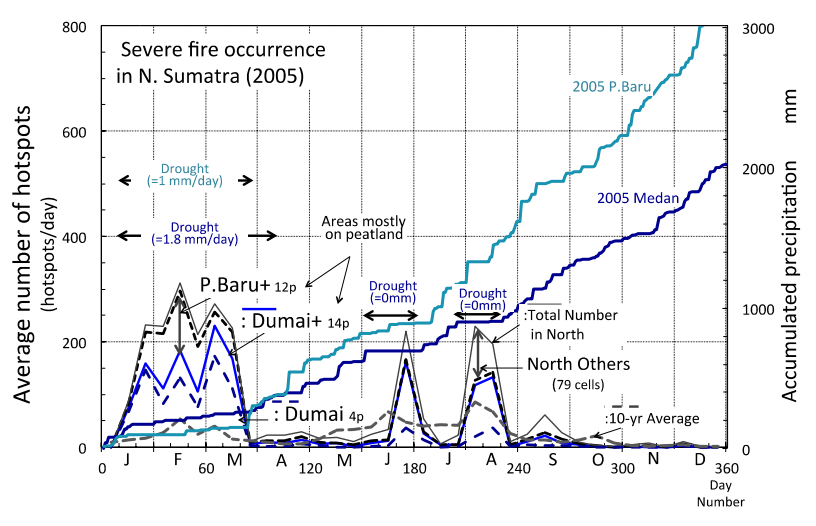

Figure 8.

Fire occurrence and accumulated precipitation in 2005.

matra are found in the various curves of hotspots and precipitation. In the figure, N. Sumatra, fire occurrence in three regions, Dumai $+14 p$, P. Baru $+12 p$, and north others (79), are arranged from bottom to top using a variety of lines. The number of hotspots in Dumai $4 p$ is shown independently by a dotted line. The difference between Dumai $+14 p$ and Dumai $4 p$ shows only the fire occurrence in the 10 grid cells in Dumai $+14 p$, and not that in Dumai $4 p$ or "Dumai $+10 p$ ". Average seasonal fire occurrence over 10-years is also shown with a dotted line to highlight the severe fire occurrence in 2005. Two accumulated curves for precipitation using two solid lines of different colors, and using daily data for P. Baru and Medan, are also included so as to evaluate the severity of the drought period.

From Figure 8, it is evident that the extreme fires of 2005 in N. Sumatra occurred in different regions and in different seasons. The most distinctive feature is that the 2005 extreme fires occurred during the dry seasons. The first extreme fires in Dumai $4 p$ (a part of Dumai $+14 p$ ) and P. Baru $+12 p$ occurred during a drought in the winter dry season $\mathrm{W}_{\mathrm{D}}$ or between mid-January and mid-March. The value of more than 100 hotspots/day was considerably higher than that of 50 hotspots/day (the 10-year average value for the whole of N. Sumatra). The following extreme fires occurred in late June in Dumai $+14 p$ (mostly in Dumai north in Table 1). The third extreme fire peak was mostly due to fires in Dumai north and North Others (79), and occurred during early and mid-August.

The extreme fires could therefore be explained by the drought conditions (using the accumulated precipitation curves in Figure 8) or by the flat part of the lines for both Medan ( 2 $\mathrm{mm} /$ day) and Pekan Baru ( $\sim \mathrm{mm} /$ day $)$. The drought conditions in 2005 are likely to have been caused by the active winter boreal monsoon occurring under El Niño Modoki or quasi-El Niño conditions (Ashok et al., 2007). This abrupt, wide area drought affected the north of Southeast Asia, and caused a rising by about +0.5 of the average EMI (El Niño Modoki Index) values between late 2004 and early 2005, as recorded by JAMSTEC (2013).

Fires in the Dumai region, (except in Dumai4), showed another two peaks in late June and in early and mid August. These fires can be explained by the short, a devastating summer drought $\left(\mathrm{S}_{\mathrm{D}}\right)$ in Medan occurring in June and August, giving the lowest precipitation rate over the past 12-years. Correspondingly, fires in North Others (mostly areas of non-peatland) became very active in late June and early August (see Figure 8) under drought during $\mathrm{S}_{\mathrm{D}}$.

\section{The Extreme Seasonal Fire Occurrence and Drought in S. Sumatra (2006)}

In Figure 9, the seasonal fire occurrence and drought in S. Sumatra are found using the various curves for hotspots and precipitation. In S. Sumatra, fire occurrence in three regions, Palembang $+16 p$, Jambi $+7 p$, and south others (72), are displayed from bottom to top using a variety of lines (in Figure 9). The number of hotspots in Palembang $6 \mathrm{p}$ is independently shown by a dotted line. The difference between Palembang + $16 p$ and Palembang $6 p$ shows only the fire occurrence within the 10 grid cells in Palembang $+16 \mathrm{p}$, and not that in Palembang $6 p$ or "Palembang $+10 p$ ". In Figure 9, the average seasonal fire occurrence over 10-years is also shown with a dotted line to illustrate the severe fire occurrence in 2006. An accumulated curve for precipitation using the daily data for Palembang was also added to evaluate the severity of the drought period (using solid lines).

From Figure 9, we can see that the 2006 extreme fires in S. Sumatra occurred in different regions and in different seasons. Of particular note, however, is that the 2006 extreme fires in S. Sumatra also occurred during the dry season. The extreme fires in Palembang $6 p$ (a part of Palembang $+16 p$ ) and Jambi $+7 p$ occurred either during a drought in summer dry season $\mathrm{S}_{\mathrm{D}}$ or from mid September to mid October. Their numbers (more than 200 hotspots/day) are considerably higher than that of the 100 hotspots/day of the 10-year average values for the whole of S. Sumatra. A catastrophic fire (about 700 hotspots/day), can be ascertained by one sharp peak in early October (twice as large as in Sampit). The worst fires in the Palembang and Jambi region coincided with the fire peak in the MRP area. About $60 \%$ of these fires in early October occurred in Palembang $6 p$ (mostly in eastern Palembang in Table 1). Fire occurrences on non-peatland (or in South Others) were in early July and August, and we are thus able to refer to these fires as "warning fires" for the areas of peatland in S. Sumatra.

The extreme fires occurred in Palembang, under a devastating long-term drought involving a period of no rain lasting about 3-months. About 3-month prior to this drought, a predrought with very low rainfall $(3.6 \mathrm{~mm} /$ day or the same rate as the annual rate in a dry season) was observed (see Figure 9). These conditions are likely to be related to the El Niño event with ONI (Ocean Niño index) values in NDJ of about +1 , as discussed in relation to Kalimantan (Yulianti \& Hayasaka, 2013).

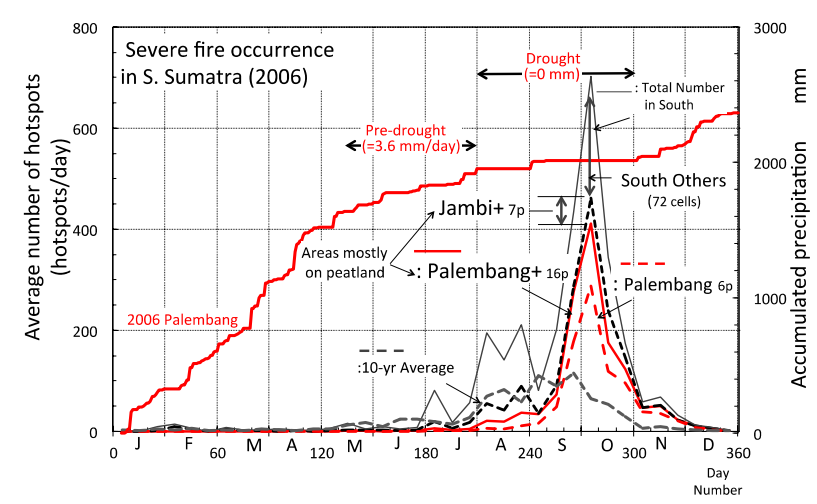

Figure 9.

Fire occurrence and accumulated precipitation in S. Sumatra (2006). 


\section{Conclusion}

Analysis results using MODIS hotspot data of the most recent 11-year period, clearly show trends of seasonal and spatial fire occurrence in Sumatra. The recent trends in fire occurrence are:

1. Two extreme fires occurred both in N. and S. Sumatra in 2005 and 2006 respectively under enhanced drought or rainless conditions related to two different types of El Niño events.

2. The highest hotspot cell found near east of Dumai in N. Sumatra contained an annual maximum number of hotspots of 4494 in 2005. The 11-year average number is $941 / \mathrm{yr}$., and this average number is slightly smaller than the 971 hotspots observed in one of cells in the MRP region (Block C south) in Kalimantan (where a maximum number of 2417 was observed in 2006). However, the annual maximum number of 4494 within the Dumai cell is the highest recorded.

3. The fifth highest hotspot cell found near eastern Palembang in S. Sumatra had a maximum number of 2966 hotspots in 2006, when the average number was $477 / y r$. This maximum number was also higher than that of 2417 in the cell in the MRP referred to above.

4. Extreme fire occurrences in N. Sumatra in 2005 and in S. Sumatra in 2006 could be partially explained by an enhanced drought occurrence due to El Niño events. But their relatively high standard deviation $(\sigma)$ values of $2.7 \sigma$ in $\mathrm{N}$. Sumatra, and $2.6 \sigma$ in S. Sumatra (higher than $1.8 \sigma$ in Kalimantan in 2006 which was the worst recent fire year for Kalimantan), suggest that both extreme fire occurrences could be classified as accidental fires. The origin of extreme fires could be from intentional fires related to practices such as land clearing and plantation development.

5. The recent fire occurrence in Sumatra was not as intense as in Kalimantan (the annual mean number of fires was about 18,000 in the whole of Sumatra and smaller than that of 23,000 in Kalimantan). Nevertheless, the peatland area in Sumatra (about $70,000 \mathrm{~km}^{2}$ ) is larger than that of Kaliman$\tan$ (about $60,000 \mathrm{~km}^{2}$ ).

6. With the exception of data from the extreme fire years, most of the annual fire occurrences in the recent 10-years lay between $+1 \sigma$ and $-1 \sigma$, except for 2010 in S. Sumatra.

7. The results of spatial analysis using $0.5^{\circ} \times 0.5^{\circ}$ cells for $\mathrm{N}$. Sumatra, clearly show one extreme fire occurrence cell (centered at $\mathrm{N} 1.75^{\circ}$ and $\mathrm{E} 101.75^{\circ}$ ) in the southeast of Dumai (one of the cells in Dumai +4 ). Within this cell, the 11-year average number of fires was 944 hotspots/year. This result was much higher than the result of the second highest cell, at 686 hotspots/year (centered at N $2.25^{\circ}$ and E $100.25^{\circ}$ ) in the northeast of Dumai (one of the cells in Dumai +14$)$.

8. In 2005, (an extreme fire year in N. Sumatra), a few clusters of hotspots were found in the southeast of Dumai (centered at around $\mathrm{N} 1.55^{\circ}$ and $\mathrm{E} 101.7^{\circ}, 30 \mathrm{~km}$ and $115 \mathrm{deg}$. from Dumai, $\mathrm{N} 1.7^{\circ}$ and E $101.5^{\circ}$ ). From these hotspot clusters, the burnt area in the southeast of Dumai was roughly estimated. During January to March (DN = $1-90)$ in 2005, the burnt area of these few clusters was estimated to be more than $700 \mathrm{~km}^{2}$.

9. In late June $2005(\mathrm{DN}=170-180)$ and in August 2005 $(\mathrm{DN}=210-230)$, fires in the northwest of Dumai (centered at around $\mathrm{N} 2.0^{\circ}$ and $\mathrm{E} 100.4^{\circ}, 120 \mathrm{~km}$ and $290 \mathrm{deg}$. from Dumai) also became active. The burnt area of these few clusters was estimated to be about $400 \mathrm{~km}^{2}$.

10. In 2006, (an extreme fire year for S. Sumatra), a few clusters of hotspots were also found in eastern Palembang (centered at around $\mathrm{S} 2.85^{\circ}$ and $\mathrm{E} 105.43^{\circ}, 76 \mathrm{~km}$ and $78 \mathrm{deg}$ from Palembang, S $3^{\circ}$ and E $104.8^{\circ}$ ). The total burned area of these hotspots clusters was estimated to be about 500 $\mathrm{km}^{2}$.

11. The above-mentioned recent fire occurrences in Sumatra were partially explained by using various precipitation patterns and dry season periods for both N. and S. Sumatra.

\section{Acknowledgements}

This research was partially supported by the JST-JICA Science and Technology Research Partnership for Sustainable Development (SATREPS) project on "Wild Fire and Carbon Management in Peat-Forests in Indonesia."

\section{REFERENCES}

Aldrian, E., \& Susanto, R. D. (2003). Identification of three dominant rainfall regions within Indonesia and their relationship to sea surface temperature. International Journal Climatology, 23, 1435-1452. http://dx.doi.org/10.1002/joc. 950

Ashok, K., Behera, S. K., Rao, S. A., Weng, H., \& Yamagata, T. (2007). El Niño Modoki and its possible teleconnection. Journal of Geophysical Research, 112, C11007. http://dx.doi.org/10.1029/2006JC003798

Badan Pusat Statistik (2010). Trends of the selected socio-economic indicators of Indonesia. Jakarta: BPS-Statistic Indonesia.

Chang, P., Wang, Z., McBride, J., \& Liu, C. H. (2005).Annual cycle of Southeast Asia-Maritime Continent rainfall and the asymmetric monsoon transition. Journal Climate, 18, 287-301. http://dx.doi.org/10.1175/JCLI-3257.1

Dennis, R. (1999). A review of fire projects in Indonesia (1982-1998). Jakarta, Indonesia: Center for International Forestry Research (CIFOR).

Fearside, P. M. (1997). Transmigration in Indonesia: Lessons from its environmental and social impacts. Environmental Management, 21, 553-570. http://dx.doi.org/10.1007/s002679900049

Furukawa, H. (2004). The ecological destruction of coastal peat wetlands in Insular Southeast Asia. In H. Furukawa, M. Nishibuchi, Y. Kono, \& Kaida, Y. (Eds.), Ecology destruction, health, and development: Advancing Asian paradigms (pp. 31-72). Nagoya: Kyoto University Press.

Harris, N. L., Brown, S., Hagen, S. C., Saatchi, S. S., Petrova, S., Salas, W., Hansen, M. C., Potapov, P. V., \& Lotsch, A. (2012). Baseline map of carbon emissions from deforestation in tropical regions. Science, 336, 1573-1576. http://dx.doi.org/10.1126/science.1217962

Indonesia Ministry of Forestry (2012). Forest statistics in 2011. Jakarta: Directorate General of Forestry Plantology.

Japan Agency for Marine-Earth Science and Technology (2013). MODOKI ENSO: A new phenomenon is found in the Tropical Pacific.

http://www.jamstec.go.jp/frcgc/research/d1/iod/modoki_home.html.en

Jauhiainen, J., Hooijer, A., \& Page, S. E. (2012). Carbon dioxide emissions from an Acacia plantation on peatland in Sumatra, Indonesia. Biogeosciences, 9, 617-630. http://dx.doi.org/10.5194/bg-9-617-2012

Joosten, H., Tapio-Biström, M., \& Tol, S. (2012). Peatlands-Guidance for climate change mitigation through conservation, rehabilitation and sustainable use. Rome: The Food and Agriculture Organization of the United Nations and Wetlands International.

Langner, A., \& Siegert, F. (2009). Spatiotemporal fire occurrence in Borneo over a period of 10 Years. Global Change Biology, 15, 4862. http://dx.doi.org/10.1111/j.1365-2486.2008.01828.x

Margono, B. A., Turubanova, S., Zhuravleva, I., Potapov, P., Tyukav- 
ina, A., Baccini, A., Goetz, S., \& Hansen, M. C. (2012). Mapping and monitoring deforestation and forest degradation in Sumatra (Indonesia) using Landsat time series data sets from 1990 to 2010. Environmental Research Letters, 7, 034010.

http://dx.doi.org/10.1088/1748-9326/7/3/034010

Miettinen, J., Hooijer, A., Tollenaar, D., Page, S., Malins, C., Vernimmen, R., Shi, C., \& Liew, S. C. (2012). Historical analysis and projection of oil palm plantation expansion on peatland in Southeast Asia. Washington DC: International Council on Clean Transportation (ICCT).

Miettinen, J., Shi, C., \& Liew, S. C. (2011a). Deforestation rates in insular Southeast Asia between 2000 and 2010. Global Change Biology, 17, 2261-2270.

http://dx.doi.org/10.1111/j.1365-2486.2011.02398.x

Miettinen, J., Shi, C., \& Liew. S. C. (2011b). Influence of peat-land and land cover distribution on fire regimes in insular Southeast Asia. Regional Environmental Change, 11, 191-2011. http://dx.doi.org/10.1007/s10113-010-0131-7

Oldeman, L. R., Darwis, S. N., \& Las, I. (1979). An agro-climatic map of Sumatra. Bogor: Central Research Institute for Agriculture.

Putra, E. I., \& Hayasaka, H. (2011). The effect of the precipitation pattern of the dry season on peat fire occurrence in the Mega Rice Project area, Central Kalimantan, Indonesia. Tropics, 19, 145-156. http://dx.doi.org/10.3759/tropics.19.145

Saharjo, B. H. (2006). Fire behavior in Pelalawan peatland, Riau Province. Biodiversitas, 7, 90-93.

Siegert, F., Ruecker, G., Hinrichs, A., \& Hoffmann, A. A. (2001). Increased damage from fires in logged forests during droughts caused by El Nino. Nature, 414, 437-440. http://dx.doi.org/10.1038/35106547

Stolle, F., Chomitz, K. M., Lambin, E. F., \& Tomich, T. P. (2003). Land use and vegetation fires in Jambi Province, Sumatra, Indonesia.
Forest Ecology and Management, 179, 277-292. http://dx.doi.org/10.1016/S0378-1127(02)00547-9

Tacconi, L. (2003). Fire in Indonesia: Causes, costs and policy implication. Bogor: Center for International Forestry Research (CIFOR).

Takahashi, H., Usup, A., Hayasaka, H., \& Limin, S. H. (2007). Overview of hydrological aspects for recent 10 years in the basins of River Sebangau and Kahayan. Environmental Conservation and Land Use Management of Wetland Ecosystem in Southeast Asia. Annual Report for April 2006-March 2007.

Uryu, Y., Mott, C., Foedad, N., Yulianto, K., Budiman, A., Setiabudi, Takakai, F., Nursamsu, S., Purastuti, E., Fadhli, N., Hutajulu, C. M. B, Jaenicke, J., Hatano, R., Siegert, F., \& Stuwe, M. (2008). Deforestation, forest degradation, biodiversity loss and $\mathrm{CO}_{2}$ emissions in Riau, Sumatra, Indonesia. Jakarta: World Wide Fund (WWF) Indonesia.

Usup, A., Hashimoto, Y., Takahashi, H., \& Hayasaka, H. (2004). Combustion and thermal characteristics of peat fire in tropical peatland in Central Kalimantan. Tropics, 14, 1-19. http://dx.doi.org/10.3759/tropics.14.1

Vadrevu, K. P., \& Justice, C. O. (2011). Vegetation fires in the Asian region: Satellite observational needs and priorities. Global Environmental Research, 15, 65-76.

Wetlands (2003). Maps of area of peatlands distribution and carbon content in Sumatra. Bogor: Wetlands International-Indonesia Programme.

Yulianti, N., \& Hayasaka, H. (2013). Recent active fire under El Niño conditions in Kalimantan, Indonesia. American Journal of Plants Science, 4, 685-696. http://dx.doi.org/10.4236/ajps.2013.43A087

Yulianti, N., Hayasaka, H., \& Usup, A. (2012). Recent forest and peat fire trends in Indonesia, the latest decade by MODIS hotspot data. Global Environmental Research, 16, 105-116. 